\title{
A Representative of the New Female Image-Analyzing Hester Prynne's Feminist Consciousness in The Scarlet Letter
}

\author{
Yamin Wang \\ Department of Foreign Languages, Tianjin University of Technology, Tianjin, China \\ Email: star.lucky@163.com
}

\begin{abstract}
The Scarlet Letter is generally considered to be Nathaniel Hawthorne's best work and one of the indubitable masterpieces of American literature. The heroine of the novel-Hester Prynne, though on a binary position as a woman in Puritan society, defies power and puts up a tenacious fight against the colonial rule combined by church and state. From her rebellious actions, we can see Hester's feminist consciousness. With this noble character, she becomes totally different from the traditional women who are always obedient to the unfair rules enacted by men. It can be sensed that a new female image is born. This paper tries to analyze Hester's feminist consciousness at the respect of her rebellious spirit, self-reliance and strong mind, in this way to evaluate Hester Prynne as a representative of the new female image. Through this kind of analysis, we can better dig in the figure of Hester, and regarding her as a new woman also has a positive social meaning in encouraging women today to strive after the lofty ideal— an equal status between men and women.
\end{abstract}

Index Terms - female image, Hester Prynne, feminist consciousness

\section{INTRODUCTION}

Nathaniel Hawthorne is regarded as one of America's few truly successful and original novelists, who's novel the Scarlet Letter has widely attracted people's attention. As an honest and thoughtful writer, Hawthorne narrates the story of Hester Prynne's miserable life, reveals women's low status of the seventeenth-century Puritan New England, and meanwhile, exposes mercilessly the cruelty and the prejudice against women of the Puritan society (Analysis of The Scarlet Letter). Although shamed and alienated from the rest of the community, Hester does not fall but becomes a miniature of a resistant, "a Feminist Angel", a strong women looking forward to the equality between men and women.

In the Scarlet Letter, Hawthorne depicts the society as it actually was in the $17^{\text {th }}$ century Puritan America, which has been considered as a reflection of women's problems at that time. Even though women are strong, brave, industrious, kindhearted, and with a lofty devoting spirit, their whole life is very tragic in the end. It deeply reveals not only the Puritan's bitterness and the women's hardship, but also the strength of the Puritan consciousness and the lowness of the women's status. This heroin of the novel, Hester Prynne, has such a noble character that she is undoubtedly recognized as a representative of the new female image.

\section{Development of Female Images}

\section{A. Traditional Female Images}

In the traditional culture, the female image always centers on two opposite aspects: the first type is the discriminated femaleness. Men and women are placed unequal positions since the day God created them. For a long time, men are considered to have rational mind and superior intelligence and the capacity for leadership. They are endowed with positive meaning and always the subjects to be praised. On the contrary, women are inferior to men at all aspects. They are more emotional and they sustain society with their nurturance, not capable of reasoning and organization. The roles, which women play, are negative. Not only is their charm denied, but also they are associated with viciousness and dissoluteness in the men's eyes.

The other type is the praiseworthy femaleness. Guan (2004) argues that after coming into the middle period in the Middle Ages, men do not attack women any more. Instead, they begin to flatter women's merits and achievements. Women are eulogized again and again for their vacations--as wives to support husbands and as parents to take care of children--and for their spirits of self-sacrifice for the family. The humanism during the Renaissance breaks up with the traditional concept that regards women as demons. In addition, it endows women with another new meaning, that is, women are like angels, rescuing men's souls and leading them to the holy paradise. However, to some degree, this so-called enhancement of women's status is not a social phenomenon but just a literature one. The excessive ideal female image does not destroy the existing sexism. To the opposite, it becomes the best excuse for men's limiting women within the small circle of family life. The reason and power still belong to men whereas what really belong to women are their beautiful bodies and frail minds. 


\section{B. The New Female Image}

The above-mentioned two types of women are designed according to men's wills to make sure the stability of men's social status. Men are able to construct philosophical, scientific, and religious systems which reinforced their dominant position, in the process defining women as less than men, almost as sub-human species, and excluding women from all sources of power. Zhang (2000) argues women are undoubtedly dependents, first of their fathers, then of their husbands, and in case of widowhood, dependents of their sons, if they had any, or of any surviving male relatives. The two types of women are under control of men, having no right of independence.

However, in the novel the Scarlet Letter, Hawthorne creates us a brand-new female image-- Hester, who is different from traditional types. Although Hester suffers enormously from the shame of her public disgrace and form the isolation of her punishment, in her inner heart she can never accept the Puritan interpretation of her act as she believes that her desire for love freedom is not evil, but with dignity and grace. Hester retains her self-respect and survives her punishment with ever-growing strength of character. She protects herself through her own thoughts, forming a new female image possessing qualities of rebellious spirit, self-reliance and strong mind. These qualities are just what feminism advocates. Therefore, the prominent difference between traditional female images and the new one lies in that the latter has the feminist consciousness. With this noble character, new women dare to defy power and put up tenacious fights against the unfair rules that determine their lower status in the society. It is the feminist consciousness awakening that enables women does things that they have never done before; moreover, this feminist consciousness embodies the inherent dignity of femaleness and highlights the worth of women.

\section{ANALYSIS OF PRYNNE'S FEMINIST CONSCIOUSNESS}

As Austin Warren has called Hester "a feminist in advance of the season", it can be seen the successful portrait of the image of Hester. In the novel, her feminist consciousness is carefully depicted, reflected at the respect of her rebellious spirit, self-reliance and strong mind. It is her feminist consciousness that endows her attractive character.

\section{A. Hester's Rebellious Spirit}

Hester's Rebellious Spirit embodies her feminist consciousness prominently. With this valuable spirit, she defies power and puts up a tenacious fight against the colonial rule combined by church and state.

1. Hester's Attitude towards Her Punishment

The Puritan society in the $17^{\text {th }}$ century America, with its freezing and self-denying doctrines cast disgrace upon the passions. Li (2006) described that the Puritan membership in the Puritan community, after all, is based on the ability of that community to judge by external signs instead of the interior conscience of men. They cannot understand the heart of humanity.

The ideal society of Puritanism is "Holy Community", so everyone of the community must comply with rules of Puritanism. The rulers do not allow anyway breaking away with the "Holy Community", let alone to revolt it.

Hester is a young and beautiful woman who has brought a child into the world with an unknown father. She is condemned to wear a scarlet letter " $\mathrm{A}$ " on her breast and suffer public shame on the scaffold. Hester rebels it, "by an action marked with natural dignity and force of character". When she walked to the scaffold from the prison, she holds her head high and remains in full public view without shedding a tear, "as if by her own will"

Hester's rebellious spirit is also reflected in the elaborate needlework of the scarlet letter. There are "fantastic flourished of gold-thread", and the letter is ornately decorative, significantly beyond the Puritan laws that call for somber, unadorned attire. She shows her skill in needling work, and it seems like that she takes pride in her token of isolation.

While she might be feeling agony as if "her heart had been flung into the street for them all to spurn and trample upon", her face reveals no such thought, and her demeanor is described as "haughty". She displays a dignity and grace that reveals a deep trust in her.

Later, the young priest Author Dimmesdale, in fact Hester's love, implores Hester to name the father of the baby and this way her penance may be lightened. To people's astonishment, she says "Never". When asked again, she says, "I will not speak!" while this declaration relieves Dimmesdale and he praises her under his breath, it also shows Hester's determination to stand alone despite the opinion of society. She uses individual rights and regards them as weapons to fire the Puritanism.

Exhausted from the punishment at the scaffold emotionally and physically, Hester is continually oppressed to wear the scarlet letter "A" on her breast all her life, which is a symbol indicating shame as a much lenient punishment. Her beautiful hair is hidden under her cap; her beauty and warmth are gone, buried under the burden of the elaborate scarlet letter. When she removes the letter and takes off her cap in the forest, Hester once again becomes the radiant beauty. Symbolically, when Hester does these actions, she is in fact removing the harsh, stark, unbending puritan social and moral structure.

Obviously, what Hester has done manifests her challenge to the whole dismal severity of the puritanical code of law. In her deepest heart, she can never accept the puritan rules and becomes a rebel against the rules. No wonder that some unkind puritans reproach her such as "what is it but to laugh in the faces of our godly magistrates, and make a pride out of what they, worthy gentlemen, meant for a punishment?”(Hawthorne, 2001, p .8) 


\section{Hester and Love}

Femaleness is always connected with love, but the presence of Hester, as the novel says, is the beginning of tragedy. She is the representative who suffers from irrational marriage. Prior to her marriage, Hester was a strong-willed and impetuous young woman - she remembers her parents as loving parents who frequently has to retain her incautious behavior. The reason why Hester marries Roger Chillingworth, the author does not give a clear answer, whereas from the sentence "it seemed a fouler offence committed by Roger, than any which had since been done him, that in the time when her heart knew no better, he had persuaded her to fancy herself happy by his side", readers can get the idea that their marriage is not based on the basis of love.

Chillingworth spends long hours over his book and experiments, paying little attention to his wife Hester. Although he is "misshapen from his birth-hour", he deludes himself with the idea that "intellectual gifts might veil physical deformity in a young girl's fantasy". Chillingworth takes Hester as a wife with the only purpose of kindling "the household fire" in his lonely and chill heart. However, his selfishness pulls Hester into the dark abyss. When Hester recalls the life spent with Chillingworth, she believes it to be "her ugliest remembrance". "She marveled how such scenes could have happen! She marveled how she could ever have been wrought upon to marry him!"

Corresponding to Chillingworth's malformation with "one of the shoulders rose higher than the other", Hester is tall, "with a figure of perfect elegance on a large scale". Even Chillingworth himself has to acknowledge "Mine was the first wrong, when I betrayed thy budding youth into a false and unnatural relation with my decay". However, to reader's surprise, this kind of abnormal marriage in under protection of puritan law and gets the recognition of the puritan public.

Hester is condemned to wear a scarlet letter "A" on her breast and suffer public shame in the scaffold. The scaffold is a painful task to bear; the townspeople gather around to gossip and stare at Hester and her newborn child Pearl. Due to her protection to her lover Dimmesdale and her desire for true love, Hester supports herself with unimaginable courage and endures unbearable misery, without telling the name of her lover. She makes up her mind to stand alone despite the opinion of the society. Hester emerges as a selfless lover making no demands on Dimmesdale and accepting her fate without ant sign of criticism. The greatness of Hester can be seen from her lover's compliment in Hawthorne's work: "wondrous strength and generosity of a woman's heart".

In order to protect the life and good fame of Dimmesdale, Hester promises to conceal her husband Chillingworth's true identity. But when she witnesses the intense misery against which the minister Dimmesdale struggle, and sees that he stands on the verge of lunacy, she determines to redeem her error to stop Chillingworth from hurting Dimmesdale further. Finally, Hester resolves to meet Chillingworth, and does what might be in her power for the rescue of the victim on whom he has so evidently set his gripe.

Hester's unflinching love to Dimmesdale is also reflected in her desire to escape with him to a new land. "Is the world, then, so narrow? Doth the universe lie within the compass of yonder town? Wither leads yonder forest track? ... There thou art free! So brief a journey would bring thee from a world where thou hast been most wretched, to one where thou mayest still be happy!" (Hawthorne, 2001, p .165) It is much to be regretted that Dimmesdale dares not quit his post. At the crucial moment, for the sake of arousing him to pragmatic idealism, Hester fervently resolves to buoy him up with her own energy. She says continually and firmly, "Thou art crushed under the seven years' weight of misery. But thou shall leave it all behind thee! ... Leave this wreck and ruin here where it hath happened. ... begin all anew! ... the future is yet full of trail and success. ... exchange this false life of thine for a true one... preach! Write! Act! Do anything save to lie down and die!" (Hawthorne, 2001, p .166) encouraged by Hester, the minister eventually resolves to flee with her. In order to give Dimmesdale encouragement and hope further, Hester, without the least hesitation, takes the scarlet letter from her bosom and throws it off, and next, she heaves a long, deep sign, in which the burden of shame and anguish departs from her spirit.

3. Hester and Her Child Pearl

Hester has a child and raises her by herself. She names the child pearl, "as being of great price — purchased with all she had-her mother's only treasure". Hester is a woman full of motherly love that she showers on Pearl. It is her love and concern for Pearl that makes her wonder her wonder if her child is abnormal. She worries about her lack of control and her shunning playmates.

In Hester's opinion, "Providence, in the person of this little girl, has assigned to Hester's change the germ and blossom of womanhood, to be cherished and developed amid a host of difficulties". (Hawthorne, 2001, p .130) However it has reached her ears that some of the leading inhabitants decide to deprive her of her child only because they cannot trust an immortal soul, such as Pearl, to the guidance of one who has stumbled and fallen amid the pitfalls of this world. Considering Hester, Pearl is her very life, her only treasure purchased with all she has. By the control of this idea, Hester defends her right to raise Pearl bravely while in the confrontation with Governor Bellingham. This is her first time to rebel and challenge the church and the secular ruler in public. Although Hester is isolated and cut off from help, and so conscious that it seems scarcely an unequal match between the puritanical magistrates, she still set forth and is ready to defend them to the death. She cries with almost a fierce expression, "God gave me the child. He gave her in requital of all things else, which she had taken from me. She is my happiness! ... Thou shall not take her! I will die first!" (Hawthorne, 2001, p .72) At this time Hester realizes that she has the responsibility and capacity to raise the child, so she repeats, raising her voice almost to a shriek, "God gave her into my keeping; I will not give her up." (Hawthorne, 
2001, p .72) Clearly, Hester, as an ordinary woman, cries out for nothing else, but for her indefeasible rights, which shows her extraordinary courage and rebellious spirit. With Dimmesdale's interference, Hester succeeds in keeping her Pearl with her.

In the novel, Hawthorne portrays Pearl with following feature: she is individual exist and escape far from the puritan society. She is a wild rose, abeam of sunlight a brook, and a lovely angel. The appearance of Pearl as Heater's daughter gifted so many virtues is a rebellion against Puritanism obviously.

In the puritan society, the mother should admonish her daughter to conform various kind of rules prescribed in the community. To be exactly speaking, the mother should teach her daughter how to be obedient to her future husband. However, being different from traditional mothers, Hester does not give Pearl this lesson. Through the scarlet letter "A", she conveys her potential maternal consciousness to Pearl, which enables her to understand female body and female passion. Wei (2003) argues that just like Hester's wish, Pearl does not follow her mother's way. She breaks the puritan rule permitting sons to have the right of succession, and accepts the inheritance from Roger. Thus Pearl becomes the richest heritress in the New Land. At last, she visits Europe and finds her lover. Pearl's happiness shows Hester's win to Puritanism and humanism's win to Puritanism.

\section{B. Hester's Self-reliance}

Recalling from her own experience, Hester believes that women are regarded as dependents upon men in the puritan society. This situation leads to women's tragic lives. With the lofty ideal of gaining self-reliance, women have to take action as soon as possible, just as what Hester thinks about:

"As a first step, the whole system of society is to be torn down, and built up anew. Then, the very nature of the opposite sex, or its long hereditary habit, which has become like nature, is to be essentially modified, before women can be allowed to assume what seems a fair and suitable position. Finally, all other difficulties being obviated, woman cannot take advantage of these preliminary reforms, until she herself shall have undergone a still mightier change ..."

By the control if this idea, Hester revolts against the social order of puritan society tenaciously. Not only has she won the self-reliance in economy, but also in thought.

1. Hester's Independence in Economy

In the Puritan society, who would succeed and who would fail are not determined by himself or herself, but by God. Man is divided into two groups. And the bad people cannot save or relieve themselves until they appeals to God's help. $\mathrm{Li}$ (2006) argues that this is a holy idea and cannot change; whereas Hester is an exception and changes it through her deeds. Though at her time, "It was the art almost the only one within a woman's grasp of needlework"; Hester possesses it that "sufficed to supply food for her thriving infant and herself". "Her needlework was seen on the ruff of the Governor; military men wore it on their scarves, and the minister on his hand; it decked the baby's little cap; it was shut up, to be mildewed and molded away, in the coffins of the dead." (Hawthorne, 2001, p .39) These noble and holy places are decorated with her fine needlework. Undoubtedly, Hester gains her self-reliance in economy without appealing to God's help. She even does not turn to her lover Dimmesdale or her husband Chillingworth, who should have been responsible for her miserable life, for help. This is the true success for the femaleness, interpreting that women are not dependents upon men. They can earn their lives with their own hands and intelligemce.

Thinking over into the deeper meaning, Hester's needlework is not only an art, but also a way for her to let off her emotions and passions. "Women derive a pleasure, incomprehensible to the other sex, from the delicate toil of the needle; to Hester it might have been a mode of expressing, and therefore soothing, the passion of her life."

2. Hester's Independence in Thought

In the puritan society, a woman should keep adherence to her husband, even she has not a bit love for him. And furthermore, she should kill her natural love within her, instead of letting it release and spoil. However, Hester does not follow this rule at all. She breaks away from her husband whom she did not love and falls in love with Dimmesdale. She dares to purse her love freedom. It can be seen from her whole story that Hester never neglects such human values as individuality, personal freedom and private life. She has her own secret. When asked about her lover's name, she says "Never!" Hester uses individual rights and regards them as weapons to fire the Puritanism.

Her self-reliance in thought is repeated again when she confronts Governor Bellingham over the issue of Pearl's guardianship. She defends the mighty power with unimagined great courage, "God gave her into my keeping, I will not give her up!" Hester's action proves that the femaleness is not the weak, but to the opposite, the strong, who is able to find out methods to rescue themselves.

For the seven solitary years, "Hester never battled with the public, but submitted; incompliantly ... she never raised her head to receive their greeting. If they were resolute to accost her, she laid her figure in the scarlet letter and passed on. " (Hawthorne, 2001, p .46) outwardly, she wears the letter that labels her as an evil woman. Inwardly, she exists in her speculations, her solitude, her quiet hours with Pearl, her needlework, and finds these good. Though "the scarlet letter by which man had marked Hester's sin had such potent and disastrous efficacy that no human sympathy could reach her", satirically, it is just the scarlet letter that becomes her passport into regions where others dare not to tread. As Hawthorne describes: "She looked form this estranged point of view at human institutions, and whatever priests or legislators have established ... The tendency of her fate and fortunes had been to set her free ... Shame, despair, solitude! These had been her teachers, stern and wide ones, and they had made her strong." (Hawthorne, 2001, p .168)

Shamed and alienated from the rest of the community, Hester becomes contemplative. She speculates on human 
nature, social organization, and large moral questions. She is able to look at the people objectively and see much she was not able to see before. "Walking to and fro, with those lonely footsteps, in the little world with which she was outwardly connected, it now and then appeared to Hester that gave her a sympathetic knowledge of the hidden sin in other hearts." The people of the town are so busy covering up their faults and hiding their human passions, that they cannot see their own or each other's faults. Hester, who wears her mark of exclusion openly, does not have to worry about the opinion of others, and gains an institution - an insight into the hearts of the people who throw out.

By the novel's end, Hester has become a proto-feminist mother figure to the women of the community. Meng (2003) describes that the shame attached to her scarlet letter is long gone. Women recognize that her punishment stemmed in part from the town father's sexism, and they come to Hester seeking shelter from the sexist forces under which they themselves suffer. This fact suggests that Hester's self-reliance in thought has gained recognition among women.

\section{CONCLUSION}

Through the whole story of The Scarlet Letter, it can be known that Hester is an extremely distinctive woman compared with traditional ones. Although suffering enormously from the shame of her public disgrace and from the isolation of her punishment, she still holds her head high and remains in full public view without shedding a tear. In order to protect her lover Dimmesdale, Hester makes up her mind to stand alone despite the opinion of society. In her inmost heart, she believes that her love to Dimmesdale is of dignity and grace. With her fine needlework, she manages to earn a living for her and her child Pearl. Hester, a woman with feminist consciousness, never falls but continually struggles against the evil forces. She dares to face her existence as a human being, especially as a woman.

All of her actions analyzed in this paper undoubtedly embody Hester's noble character of rebellious spirit, self-reliance and strong mind, which is exactly what feminism advocates. It can be concluded that Hester, with the feminist consciousness, has become the representative of a new female image, just as Nina (2000) describes, "In portraying the figure of Hester, Hawthorne creates the first real female protagonist as well as one of unforgettable heroines in American novel."(Nina. B. 2000)

Therefore, the definition of the new female image has come out, that is, one with the feminist consciousness. This kind of femaleness dares to trust her and to believe in the possibility of a new morality in the world, thus they are able to reform the old world and create a new one instead. In the novel, Hester indeed sets a typical example; unfortunately, owing to some limitations, such as he owns human weakness and the prejudice of the Puritan society, she cannot become a thorough feminist. In spite of this, the image of Hester plays an active role in promoting of feminism later. Through her life, Hawthorne puts forward a serious and considerable subject: How can women gain their deserved rights of equality and freedom? Li (2004) argues that although Hester does not realize her ideal, her new female image with the feminist consciousness will encourage women today to strive after the lofty ideal.

\section{ACKNOWLEDGMENT}

The authors wish to express my deepest gratitude to my supervisor, Professor Xu Jianzhong, who has done a great favor to my thesis. From the planning of the questionnaire to the revision of the thesis, I have benefited greatly from his patience, encouragement and excellent guidance. What's more, I am deeply moved by his serious attitude towards academic work.

\section{REFERENCES}

[1] Guan Tao. (2004). A New Female Image-Female of the Third Type. Journal of Xi'an International Studies University 12.1, $55-58$.

[2] Hawthorne, N. (2001). The Scarlet Letter. World Publishing Corporation Shanghai.

[3] Li Yueling. (2006). Hester Prynne, a Heroine of Anti-Puritanism. Journal of Yulin Teachers College 27.1, 32-36.

[4] Li Zheng. (2004). Hawthorne's Feminist Consciousness Implied in the Scarlet Letter. Journal of Yueyang Higher Vocational and Technical College 19.2, 68-70.

[5] Meng Xueqin. (2003). Does Hester Get Rebirth?-Reexamination of the Heroine in The Scarlet Letter. Journal of PLA University of Foreign Languages 26.6, 79-82.

[6] Nina, B. (2000). The Scarlet Letter: A Reading. Boston: Twyne publisher.

[7] Warren, A. (1998). Theory of Literature. New York: Greenwood Press.

[8] Wei Jianghua. (2003). A Brief Comment on The Scarlet Letter of Hawthorne. Journal of Ningxia University (Social Science Edition)25. 4, 81-85.

[9] Zhang Shuling, Cheng Yunhua. (2000). Rebellious Hester in Hawthone's The Scarlet Letter from the point of view of feminism. Journal of Guanghzhou Normal University (Soclal Science Edition) 21.10, 16-19.

Yamin Wang was born in Henan, China in 1984. He is a post-graduate student and will receive his M.A. degree in linguistics from Tianjing University of Technology, China in 2011. His research interests include systemic-functional linguistics and American literature. 